AGRICULTURE AND BIOLOGY JOURNAL OF NORTH AMERICA

ISSN Print: 2151-7517, ISSN Online: 2151-7525, doi:10.5251/abjna.2013.4.4.370.374

(C) 2013, ScienceHuß, http://www.scihub.org/ABJNA

\title{
Seed borne fungi of Chilli Pepper (Capsicum frutescens) from pepper producing areas of Benue State, Nigeria
}

\author{
Ekhuemelo Chigoziri and Ebenezer Jonathan Ekefan
}

\author{
Department of Crop and Environmental Protection, \\ Federal University of Agriculture, Makurdi, Nigeria. \\ chigondu@yahoo.com
}

\begin{abstract}
A field survey was conducted in Gboko and Ohimini Local Government Areas of Benue State where pepper is extensively cultivated to investigate the seed borne diseases of two Chilli pepper (Capsicum frutescens) types namely: 'Sombo' and Birdeye. Naturally infected pepper seeds were extracted from pepper fruits collected from farmers' fields between August and October, 2011 from the two Local Government Areas (LGAs). Using agar plate method a total of 20 genera and 36 species from three classes of fungi were isolated and identified from 800 seed samples of pepper. Colletothrichum capsici, Aspergillus niger and A. flavus were the most frequently isolated fungi with $54.75 \%, 44.00 \%$ and $29.75 \%$ occurrence respectively. C. capsicilA.niger interaction had the highest occurrence of $3 \%$ followed by A.flavus/A. niger interaction with $1.25 \%$. Nematode/fungi association had $26.25 \%$ occurrence on pepper seeds. Phoma spp, Humicola fuscoatra, Humicola dimorphospora, Bispora betulina, Phomopsis spp,Botryotrichum piluferum, Periconia byssoides, Coniothyrium fuckelii, Fumago spp, Septonema chaetospira and Syncephalotrichum racemosum are being reported on pepper seeds for the first time in Benue State. Detection of the seed borne fungi is important in the management of pepper diseases and can be a useful guide to strategic disease control.
\end{abstract}

Keywords: Colletotrichum capsici, fungi, agar, pepper

\section{INTRODUCTION}

Pepper is one of the five most important vegetable crops used in Nigeria as condiment and food flavour. Chilli pepper (Capsicum frutescens) cultivation has existed for several hundred years as a sustainable form of agriculture. Chilli pepper is one of the cash crops produced in Benue States usually exported to neighbouring states (BENSEED, 2004). Capsicum frutescens exists as an annual herbaceous vegetable or perennial shrub of the Solanacae family (Amusa et al., 2004).It is a spice grown in both tropical and subtropical regions (Than et al., 2008). Pepper is also suitable for the diets of the obese and is useful in the control of cancer of the stomach and colon (Pamplona-Roger, 2007). Chilli peppers are low in sodium, cholesterol free, rich in vitamins $A$ and $C$, and are a good source of potassium, folic acid and vitamin $\mathrm{E}$ (Than et al, 2008). Fresh green chilli peppers contain more vitamin $C$ than citrus fruits and fresh red chilli has more vitamin A than carrots (Than et al, 2008). C. capsicum fruits are used in sauces, soups, stews and generally as a flavouring agent(Amusa et al.,2004) The different varieties of pepper provide income for women and children who cultivate it in large quantities (Amusa et al., 2004).
Seed is an important input for crop production. About $90 \%$ of the world food crops including Chilli pepper (C. frutescens) are propagated by seed (Maude, 1996). Seeds are the passive carriers of some important seed borne diseases caused by microorganisms which usually result in considerable yield losses. Fungi, bacteria, viruses and nematodes can be carried with, on or in seeds. The use of healthy seeds is important for crop establishment, yield and productivity. Seed testing is needed to achieve this. Although several workers have reported isolation of various fungi from vegetable seeds (Alkassim and Monawar, 2000; Balogun et al., 2005; Maleko, 2010), there are no reports of the pathogenic seed borne fungi of pepper in Benue State. Early identification and listing of plant pathogens in an area allows for timely development of control and management strategies that goes a long way in avoiding epidemics and crop losses. It is also a means of checking the spread of many seed borne diseases and ensures the prevention of the spread of plant diseases to new areas.

The present study was undertaken to investigate the fungi pathogens associated with pepper seeds in two 
pepper producing Local Government Areas of Benue State, Nigeria.

\section{MATERIALS AND METHODS}

Naturally infected pepper fruits were obtained from farmers' pepper farms between August and October, 2011 from Gboko and Ohimini Local Government Areas of Benue State.

Seeds were extracted from the fruit of two hot pepper popularly cultivated in these areas viz: 'Sombo'(C.frutescens) from Gboko LGA and Birdeye (C. frutescens) from Ohimini LGA. The seeds were surface sterilized for $3 \mathrm{~min}$ in a $1.0 \%$ solution of sodium hypochlorite to remove surface fungi. To test the seeds for mycofloral contamination, standard agar plate method was used. Potato Dextrose Agar (PDA) containing streptomycin antibiotics was used. The experiment was a completely randomized design with eight replicates. A total of four hundred seeds (fifty seeds per replicate) were plated per Local Government giving a total of eight hundred seeds for the two Local Government Areas. Seeds were incubated for seven days at ambient conditions of light and temperature. Fungal organisms were identified by preparing slides and viewing spores under compound microscope (X40-X 100 magnifications) for the presence of fungi. Isolated fungi were identified using reference manual (Watanabe, 2010). Infection levels were recorded as the percentage of infected seeds in a sample.

\section{RESULTS}

The incidences of the fungi isolated from pepper seeds obtained from the two Local Government Areas are shown in Table 1. The occurrences of seed borne mycoflora varied between the two Local Government Areas. Percentage occurrence ranged from $0.25 \%$ to $54.75 \%$. More fungi were detected on pepper seeds from Ohimini LGA than from Gboko LGA. Gboko LGA had twenty three species from 12 genera while Ohimini LGA had twenty six species from 14 genera (Table 1). Phoma spp, Humicola fuscoatra, Humicola dimorphospora, Bispora betulina, Phomopsis spp, Botryotrichum piluferum ,Periconia byssoides, Coniothyrium fuckelii, Fumago spp, Septonema chaetospira and Syncephalotrichum racemosum are being reported on pepper seeds for the first time in Benue State.. Colletotrichum capsici with the highest frequency of $54.75 \%$ occurred more in Gboko $(33.50 \%)$ than in Ohimini LGA $(21.25 \%)$ (Table1). C.coccodes a pathogen infecting tomato was found to infect pepper in Gboko LGA where tomato is extensively grown suggesting that pepper is an alternative host of the fungus in that LGA.
Table 1: Classification and Percentage (\%) occurrence of seed borne fungi isolated from pepper seeds in two LGAs of Benue State.

\begin{tabular}{|c|c|c|c|}
\hline Class of Fungi & Fungi & Gboko & Ohimili \\
\hline \multirow[t]{29}{*}{ Anamorphic } & Colletotrichum capsici & 33.50 & 21.25 \\
\hline & $\begin{array}{l}\text { Colletotrichum } \\
\text { coccodes }\end{array}$ & 0.25 & - \\
\hline & $\begin{array}{l}\text { Colletotrichum } \\
\text { dematium }\end{array}$ & 1.00 & - \\
\hline & Aspergillus niger & 24.50 & 19.50 \\
\hline & Aspergillus flavus & 11.50 & 18.25 \\
\hline & Aspergillus fumigatus & 0.25 & 0.25 \\
\hline & $\begin{array}{l}\text { Aspergillus } \\
\text { parasiticus }\end{array}$ & 2.25 & 2.25 \\
\hline & Aspergillus sect wentii & 0.25 & - \\
\hline & $\begin{array}{l}\text { Aspergillus sect } \\
\text { clavati }\end{array}$ & 0.25 & 0.25 \\
\hline & Aspergillus brevipes & 1.50 & 0.25 \\
\hline & Rhizoctonia solani & 0.50 & 0.75 \\
\hline & Phoma spp & 0.25 & 0.25 \\
\hline & $\begin{array}{l}\text { Penicillium } \\
\text { corylophilum }\end{array}$ & - & 0.25 \\
\hline & $\begin{array}{l}\text { Penicillium } \\
\text { janthinellum }\end{array}$ & - & 0.25 \\
\hline & Fusarium solani & - & 1.25 \\
\hline & $\begin{array}{l}\text { Fusarium } \\
\text { ventrichosum }\end{array}$ & - & 0.50 \\
\hline & Fusarium oxysporum & - & 1.00 \\
\hline & Alternaria longipes & - & 0.25 \\
\hline & $\begin{array}{l}\text { Humicola } \\
\text { dimorphospora }\end{array}$ & 1.75 & - \\
\hline & Humicola fuscoatra & 0.25 & - \\
\hline & $\begin{array}{l}\text { Botryodiplodia } \\
\text { theobromae }\end{array}$ & - & 1.50 \\
\hline & Botryotrichum spp & - & 0.50 \\
\hline & $\begin{array}{l}\text { Botryotrichum } \\
\text { piluliferum }\end{array}$ & - & 0.25 \\
\hline & Bispora betulina & - & 0.25 \\
\hline & Phomopsis spp & 1.00 & - \\
\hline & Periconia byssoides & - & 0.25 \\
\hline & Coniothyrium fuckelii & 1.50 & - \\
\hline & Fumago spp & - & 0.25 \\
\hline & $\begin{array}{l}\text { Septonema } \\
\text { chaetospira }\end{array}$ & 0.25 & - \\
\hline \multirow[t]{4}{*}{ Oomycota } & $\begin{array}{l}\text { Pythium } \\
\text { aphanidermatum }\end{array}$ & 2.25 & 0.50 \\
\hline & Pythium elongatum & 0.25 & 0.25 \\
\hline & Pythium graminicola & - & 2.50 \\
\hline & Pythium inflatum & 0.25 & 0.25 \\
\hline \multirow[t]{3}{*}{ Zygomycota } & Mucor microsporus & 0.25 & - \\
\hline & Rhizopus oryzae & 1.50 & 1.00 \\
\hline & $\begin{array}{l}\text { Syncephalastrum } \\
\text { racemosum }\end{array}$ & 0.25 & - \\
\hline & & & \\
\hline
\end{tabular}

Damping off fungi was more in Ohimini LGA than in Gboko LGA. Soil borne pathogens such as Fusarium solani, Mucor spp , Pythium spp and Rhizoctonia solani were found to infect pepper seeds 
in this study with percentage occurrence of $0.25 \%$ $2.50 \%$ ((Table 1).

Penicillium and Fusarium spp were not detected in Gboko LGA. Twenty nine species of anamorphic fungi were isolated in comparism with four Oomycota species and three Zygomycota species (Table 2).

Table 2: Classification and number of species of seed borne fungi isolated from pepper in Gboko and Ohimili LGAs of Benue State.

\begin{tabular}{|l|c|}
\hline Class of fungi & Number of species isolated \\
\hline Zygomycota & 3 \\
\hline Oomycota & 4 \\
\hline Anamorphic & 29 \\
\hline
\end{tabular}

Seven species of Aspergillus were detected of which Aspergillus niger was highest with $24.50 \%$ in Gboko LGA followed by $A$. flavus with $19.50 \%$ in Ohimini LGA.

The isolated fungi having $1.25 \%$ or more incidences on pepper seeds were designated as major seed borne fungi (Table 3)

Table 3: Infection percentages and diseases caused by major seed borne fungi isolated from pepper samples in Gboko and Ohimini LGAs of Benue State.

\begin{tabular}{|l|l|l|l|}
\hline Fungi & $\begin{array}{l}\text { Common/Disease } \\
\text { Name }\end{array}$ & $\begin{array}{l}\text { Effect(s) } \\
\text { on Crops }\end{array}$ & $\begin{array}{l}\% \\
\text { Infection }\end{array}$ \\
\hline $\begin{array}{l}\text { Colletotrichum } \\
\text { capsici }\end{array}$ & Anthracnose & ripe rot & 54.75 \\
\hline Aspergillus niger & $\begin{array}{l}\text { Crown rot/collar } \\
\text { rot }\end{array}$ & $\begin{array}{l}\text { damping } \\
\text { off, } \\
\text { seedling rot }\end{array}$ & 44.00 \\
\hline $\begin{array}{l}\text { Aspergillus } \\
\text { flavus }\end{array}$ & Yellow mold & $\begin{array}{l}\text { reduced } \\
\text { seed } \\
\text { viability }\end{array}$ & 29.75 \\
\hline $\begin{array}{l}\text { Aspergillus } \\
\text { parasiticus }\end{array}$ & Aflatoxin mold & $\begin{array}{l}\text { Reduced } \\
\text { seed quality }\end{array}$ & 4.50 \\
\hline $\begin{array}{l}\text { Pythium } \\
\text { graminicola }\end{array}$ & Water mold & $\begin{array}{l}\text { damping } \\
\text { off/root rot }\end{array}$ & 2.50 \\
\hline $\begin{array}{l}\text { Pythium } \\
\text { aphanidermatum }\end{array}$ & Water mold & $\begin{array}{l}\text { damping } \\
\text { off/root rot }\end{array}$ & 2.75 \\
\hline Rhizopus oryzae & $\begin{array}{l}\text { Rhizopus } \\
\text { rot/bread mold }\end{array}$ & soft rot & 2.50 \\
\hline Fusarium solani & Fusarium stem rot & root rot/wilt & 1.25 \\
\hline $\begin{array}{l}\text { Rhizoctonia } \\
\text { solani }\end{array}$ & $\begin{array}{l}\text { Rhizoctonia seed } \\
\text { rot }\end{array}$ & $\begin{array}{l}\text { lack of seed } \\
\text { germination }\end{array}$ & 1.25 \\
\hline $\begin{array}{l}\text { Botryodiplodia } \\
\text { theobromae }\end{array}$ & Stem - end rot & $\begin{array}{l}\text { fruit rot/die } \\
\text { back }\end{array}$ & 1.50 \\
\hline $\begin{array}{l}\text { Coniothyrium } \\
\text { fuckelii }\end{array}$ & $\begin{array}{l}\text { Coniothyrium } \\
\text { canker }\end{array}$ & $\begin{array}{l}\text { Stem } \\
\text { cankers }\end{array}$ & 1.50 \\
\hline
\end{tabular}

Table 4 and 5 shows the incidence of fungi and nematodes in pepper seeds from Gboko and Ohimini LGA in Benue State. In all, eleven fungi were associated with nematodes.
Fungi/Fungi co-existence occurred in $7.0 \%$ of the seeds with C.capsici /A.niger having the highest occurrence of $3 \%$ (Table 4).Fungi/Nematode association in pepper seeds from the two LGAs was $26.25 \%$ with Gboko having the highest occurrence of 20.75\% and Ohimini 5.50\% (Table 6). C. capsici and seed borne nematode occurred together in $7.50 \%$ of the seeds from Gboko and had as low as $2.50 \%$ incidence in Ohimini LGA (Table 5).

Table 4: Percent occurrence of fungi Co-existing in pepper seeds from Gboko and Ohimini LGAs

\begin{tabular}{|l|l|l|}
\hline Fungi & $\begin{array}{l}\text { Percent } \\
(\%)\end{array}$ \\
\hline & Gboko & Ohimini \\
\hline C.capsici/A.niger & 3.00 & 2.00 \\
\hline C.capsici/P.aphandermatum & 0.50 & 0.50 \\
\hline C.capsici/P. graminicola & - & 0.25 \\
\hline C.capsici/A. flavus & 0.25 & 0.50 \\
\hline C.capsici/A. parasiticus & 0.25 & 0.75 \\
\hline C.capsici/A. brevipes & 0.25 & - \\
\hline A.flavus/A.niger & 1.25 & 11.50 \\
\hline A.flavus/A.fumigatus & 1.25 & - \\
\hline & & \\
\hline
\end{tabular}

Table 5: Incidence of fungi and nematodes in pepper seeds from two LGAs of Benue State.

\begin{tabular}{|l|l|l|}
\hline Incidence & $\begin{array}{l}\text { Percent } \\
\text { (\%) }\end{array}$ & \multicolumn{2}{l|}{ occurrence } \\
\hline Fungi/Nematode & Gboko & Ohimini \\
\hline & & \\
\hline C. capsici+nematode & 7.50 & 2.50 \\
\hline A. parasiticus+nematode & - & 0.75 \\
\hline A. flavus+nematode & 3.00 & 0.25 \\
\hline A. niger+nematode & 2.00 & 1.00 \\
\hline P.aphanidermatum+nematode & 0.25 & - \\
\hline A. Sp. Sect Wenti+nematode & 2.50 & - \\
\hline $\begin{array}{l}\text { H. dimorphospora+nematode } \\
\text { M. microsporus+nematode }\end{array}$ & 0.25 & - \\
\hline S. chaetospira+nematode & 1.00 & - \\
\hline Phoma spp+ nematode & 0.50 & - \\
\hline C.dematium+nematode & 0.25 & - \\
\hline Fungi+fungi/Nematode & 1.50 & - \\
\hline C.capsici+A.niger+nematode & 1.50 & 1.25 \\
\hline $\begin{array}{l}\text { P.elongatum+P.aphanidermatu } \\
\text { m+nematode }\end{array}$ & 0.50 & - \\
\hline
\end{tabular}


Table 6: Incidence of fungi and nematodes according to location

\begin{tabular}{|l|l|l|}
\hline Incidence & \multicolumn{2}{|l|}{ Percent occurrence \% } \\
\hline & Gboko & Ohimini \\
\hline Fungi/nematode & 18.75 & 4.25 \\
\hline Fungi+fungi+nematode & 2.00 & 1.25 \\
\hline
\end{tabular}

\section{DISCUSSIONS}

The results of this study reveal that seed borne pathogens are present in most of the pepper seeds although in certain instances they occurred in trace levels. Majority of the pathogens persist on seeds which possibly explains why isolated fungi were mainly seed borne. Diagnoses of seed borne pathogens will allow for the development of control strategies and prevention of disease spread to other areas of the state.

The fungi isolated from pepper seeds are a reflection of the possible diseases that could affect pepper seeds and seedlings emerging from such infected seeds. Seed-borne infections appear to be common in seed samples collected from affected fields (Nayaka et al., 2009). Many of the isolated fungi have been reported to be pathogenic to the seeds of different crops causing diseases such as seed rot, damping off, root rot, fruit rot, wilt and foliar diseases (Al- kassam and Monawar, 2000). Some of the seedborne fungi are also known to cause seed rot, decrease seed germination and cause pre and post damping off and seedling death (Al-kassam and Monawar, 2000). Anjorin and Mohammed (2009) reported that factors such as moisture content of the seed, temperature and the degree of invasion of seed by pathogens influenced the development of seed borne fungi. $A$. flavus and $A$. parasiticus has also been reported to produce aflatoxins, which are toxic metabolites harmful to humans and causes damage to fruits and seeds of host plant (Balogun et al., 2005).

In a study by Balogun et al. (2005), Penicillium digitatum, Aspergillus flavus and Aspergillus niger were isolated from pepper fruits and seeds and were demonstrably pathogenic on pepper fruits. This report collaborates the isolation of $A$. niger, $A$. flavus, Penicillium corylophilum and Penicillium janthinellum from pepper seeds in this study. Seeds attacked by Rhizoctonia solani, Fusarium spp,and Pythium spp usually fail to germinate resulting in poor stand development (Goldberg, 2011). Plants are vulnerable to infection by $P$. aphanidermatum during germination and juvenile stages resulting in pre-emergence damping off (Parker, 1999).
Anjorin and Mohammed (2009) reported a strong relationship between $P$. aphanidermatum inoculum density, growth and yield of host plant. Although the percentage occurrence of some fungi was low, studies have shown that a small percentage of infection in a seed lot is enough to cause epidemics. In Uganda, infections of $0.3-16.1 \%$ were found in farmers, commercial and research seeds and $0.2 \%$ seed infection level resulted in serious disease incidence (Makelo, 2010). Makelo (2010) reported that seed contamination contributes to initial infections and that one infected seed in 10,000 was sufficient to cause bacterial disease epidemics in dry beans while one percent seed infection in tomato transplants caused $100 \%$ Clavibacter michiganensis subsp. michiganensis infection. Although $P$. graminicola is reported to be the most common pathogen of rice (Kobori et al., 2004), it was found to be present in pepper from Ohimini LGA. C. coccodes which infects tomato was found to be present in pepper from Gboko LGA where tomato is extensively cultivated suggesting pepper as an alternative host in that area. The fungus Coniothyrium fuckelii has been reported to cause liver infection ( Kiehn et al., 1987). The spread of $C$. fuckelii should be promptly curtailed to prevent the incidence of liver infection among pepper farmers.

Although soil borne fungi occurred in trace levels, their build up and spread could be enhanced by the planting of infected seeds. This can be prevented by encouraging farmers to plant clean and healthy seeds since majority of farmers from these areas plant seeds saved from their previous harvest.

The fungus $C$. capsici causal agent of pepper ripe rot which persists in infected seed, crop debris, and alternate hosts (Goldberg,2011) had high incidence in this study suggesting that anthracnose disease will be on the increase in these two Local Government Areas.

The interaction of nematodes with fungi may act synergistically to incite disease. Plant parasitic nematodes interact with fungi to cause plant disease complexes and may also increase the severity of disease (Senthamarai et al., 2008). According to Haseeb et al. (2005) low densities of fungi or nematode can result in a disease complex of significant importance. Associations between fungi and nematodes have been found to cause brown rot of tobacco. Also, disease associations between Rhizoctonia solani and root lesion nematode Pratylenchus minyus have been closely and consistently associated with natural infections of 
winter wheat in the pacific North West resulting in root rot, stunting and yield reduction of wheat (Mckenry and Roberts, 1985). Research into the economic importance of seed borne diseases of pepper with regards to yield losses resulting from these fungal pathogens is recommended.

\section{CONCLUSION}

The incidence of seed borne fungi and plant parasitic nematodes on pepper seeds from the surveyed areas reveal the health of seeds from farmers' field and indicates the possibility of disease occurrence when such infected seeds are planted.

\section{REFERENCES}

Al- Kassim, M.Y and M.N.Monawar (2000). Seed-borne Fungi of Some Vegetable Seeds in Gazan Province and Their Chemical Control.Saudi J. of Biol. Sci. Vol 7 (2): $179-185$

Amusa, N.A.,Kehinde I.A. and A.A. Adegbite (2004). Pepper fruit anthracnose in the humid forest of southwestern Nigeria. Nutrition and Food Science 34(3):130-134.

Anjorin, S.T. and M. Mohammed (2009). Effects of Seedborne Fungi on Germination and Seedling Growth of Watermelon (Citrullus lanatus). J. Agric. Soc. Sci., 5: 77-80

Balogun, O.S., Odeyemi, G. A. and Fawole, O.B. ( 2005). Evaluation of the pathogenic effect of some fungal isolates on fruits and seedlings of pepper (Capsicum spp) J. Agric. Res. \& Dev 2005 Vol 4 (2): 159-169.

BENSEED (2004). Benue State economic empowerment and development strategy. Second draft strategy Report Pp132.

Goldberg N. P. (2011) Chile Pepper Diseases Circular 549 Consumer and Environmental Sciences New Mexico State University

Haseeb,A.Sharma.A. and P.K. Shula (2005). Studies on the management of root knot nematode, Meloidogyne incognita- wilt fungus, Fusarium oxysporum disease complex of green gram, Vigna radiata cv ML-1108. J. of Zhejiang Uni. Sci. B. 6(8):736- 742.
Kiehn T.E., B. Polsky, E. Punithalingam, F.F. Edwards, A.E.Brown and D. Armstrong (1987). Liver infection caused by Coniothyrium fuckelii in a patient with acute myelogenous leukemia.J.Clin. Microbiol. Dec 25(12):2410-2412

Kobori, H., T, M. N. Hasunuma,. and S. T. Ohki (2004). Materials of Pythium Flora in Japan (XI): Characterization of Pythium graminicola causing seedling blight in rice.

Makelo M. N. (2010). Assessment of seed borne pathogens for some important crops in Western Kenya, Machakos Kenya, PP1-7.

Maude,R.B.(1996).Seed borne diseases and their Control. CAB Inter. Cambridge Pp.280.

Mckenry, M.V. and P.A. Roberts (1985). Nematode/fungus interactions .Phytonematology study guide: University of California, Division of Agriculture and Natural Resources Publication 4045.

Nayaka,C.S., A.C.U.Shankar, S.R. Niranjana, H.S. Prakash and C.N. Mortensen (2009). Anthracnose disease of chilli pepper T e c h n i c a I bu I le t i n

Pamplona-Roger G.D. (2007). Healthy Foods, Editorial Safeliz, Spain Pp375.

Parker,K.C.(1999). Pythium aphanidermatum Soilborne pathogen PP728 class project. North Carolina State University.

Senthamarai, M.P., K. S. Subramanian, and M.J. Sudheer (2008). Nematode-fungal disease complex involving Meloidogyne incognita and Macrophomina phaseolina on medicinal coleus, Coleus forskohlii Briq.Indian Journal of Nematology Vol 38(1):30-33.

Than, P; Prihastuti H; Phoulivong S; Paul W; Taylor J and Hyde K.D. (2008). Chilli anthracnose disease caused by Colletotrichum species. International symposium on fungal diversity Oct 16-19 Hangzhou China.

Watanabe, T. (2010). Pictorial atlas of soil and seed fungi: Morphologies of cultured fungi and key to species, 3rd edition. American Phytopathology Society press. pp 440 